\title{
Diagnostic proficiency and reporting of Lassa fever by physicians in Osun State of Nigeria
}

\author{
Samuel Anu Olowookere ${ }^{*}$, Akinola Ayoola Fatiregun², Olalere Omoyosola Gbolahan ${ }^{3}$ and Ebenezer Gbenga Adepoju ${ }^{4}$
}

\begin{abstract}
Background: Lassa fever is highly contagious and commonly results in death. It is therefore necessary to diagnose and report any suspected case of Lassa fever to facilitate preventive strategies. This study assessed the preparedness of physicians in the diagnosis and reporting of Lassa fever.

Methods: The study design was descriptive cross-sectional. The consenting medical doctors completed a self-administered questionnaire on the diagnosis and reporting of Lassa fever. Descriptive and inferential statistics were used in data analyses.

Results: One hundred seventy-five physicians participated in the study. The mean age was $41.5 \pm 10.9$ years (range, 24-75 years). Most of the physicians were male (78.9\%) and had practiced medicine $\geq 20$ years (51.5\%). Most of the physicians had a good knowledge regarding the diagnosis and reporting of Lassa fever; however, none of the physicians had ever diagnosed or reported a suspected case. Predictors of good knowledge include male sex, not practicing at a secondary health care level and post graduation year more than 20 years.

Conclusion: There is disparity in knowledge and practices of physicians regarding the diagnosis and reporting of Lassa fever. Thus, it is necessary to improve the knowledge and practices of physicians regarding the diagnosis and reporting of Lassa fever.
\end{abstract}

Keywords: Assessment, Diagnosis, Reporting, Lassa fever, Nigerian physicians

\section{Background}

Lassa fever is a viral haemorrhagic fever caused by a rodent-borne arenavirus that is endemic to West Africa [1-3]. Arenaviruses are emerging in the African continent and can cause haemorrhagic fevers with case fatalities between $10 \%$ and $20 \%[4,5]$. These viruses are mainly transmitted through contact with the excreta of the natural host (rodents of the family Muridae) [6-8]. The Old World arenavirus, Lassa virus, causes up to 300,000 cases of Lassa fever annually in West Africa [9-11]. In the 1970s the rodent host of Lassa virus was classified as Mastomys natalensis. Other rodent hosts, such as M. erythroleucus, and the Rattus and Mus genera, have been suggested [12-14]. Health care workers are predominantly infected and likely to die from Lassa fever in the central and southern parts of Nigeria, most

\footnotetext{
* Correspondence: sanuolowookere@yahoo.com

'Department of Community Health, Faculty of Clinical Sciences, College of Health Sciences, Obafemi Awolowo University, lle-lfe, Osun state, Nigeria Full list of author information is available at the end of the article
}

often due to poor medical practices, late diagnosis, and treatment $[10,15]$. The establishment of diagnostic facilities that can provide rapid molecular testing at referral centers in the disease-endemic zones has been suggested as a partial solution to this problem. This testing would facilitate appropriate case and contact management, including early treatment and post-exposure prophylaxis with Ribavirin, and eventually raise awareness that Lassa fever should be considered in every severe febrile illness in these regions of Nigeria and West Africa [14,16].

Although no previous cases of Lassa fever has been reported in the State of Osun in Nigeria, outbreaks of the disease were reported in several states of Nigeria including nearby Edo state.

In the first quarter of 2012, 623 suspected cases, including 70 deaths were recorded from 19 of the 36 States of Nigeria. Laboratory analysis undertaken at the Irrua Specialist Teaching Hospital, Irrua Edo State, Nigeria confirmed the presence of Lassa virus infection in 108

\section{Biomed Central}

(c) 2014 Olowookere et al.; licensee BioMed Central Ltd. This is an Open Access article distributed under the terms of the Creative Commons Attribution License (http://creativecommons.org/licenses/by/2.0), which permits unrestricted use, distribution, and reproduction in any medium, provided the original work is properly credited. The Creative Commons Public Domain Dedication waiver (http://creativecommons.org/publicdomain/zero/1.0/) applies to the data made available in this article, unless otherwise stated. 
patients. Three doctors and four nurses were among the fatalities [17].

Since medical doctors are the first point of contact in diagnosing and reporting cases of Lassa fever, it is imperative to conduct baseline studies to assess the diagnostic knowledge and reporting of Lassa fever among physicians in Nigeria, hence the need for this study.

This study determined the preparedness of physicians in the diagnosis and reporting of Lassa fever.

\section{Methods}

\section{Study setting}

Osun state is one of 36 states in Nigeria, and is located in the southwestern part of Nigeria. Osun state is bounded on the north by Kwara state, on the east by Ekiti and Ondo states, on the south by Ogun state, and on the west by Oyo state. Osun state has 30 local government areas with several maternity centres, comprehensive health centres, and state hospitals spread across the state. Also, LAUTECH Teaching Hospital, Osogbo and Obafemi Awolowo University Teaching Hospital Complex, Ile-Ife are situated in Osun state. As at the time this study was conducted, about 600 medical doctors practice medicine in Osun state.

\section{Study design}

This was a descriptive cross-sectional study conducted in the month of June, 2013. All physicians attending a Nigerian Medical Association (NMA)-organized Continuing Medical Education programme at the NMA house in Osogbo, which is a requirement for annual licensure, were approached, after taken their consent.

\section{Data collection}

A validated (face validity) semi-structured, self-administered questionnaire was used to obtain data on the respondents sociodemographic characteristics, knowledge, diagnosis, management and reporting of Lassa fever.

\section{Data analysis}

The data obtained were entered into SPSS version 16 and analyzed as frequencies for categorical variables, and mean and standard deviation for continuous variables. Knowledge score was computed for a 19-item question on general knowledge of Lassa fever. Each item was assigned ' +1 ' for correct knowledge and ' 0 ' for incorrect knowledge. The knowledge score was graded as good or appropriate (if respondent scored $\geq 10$ points), and not good or not appropriate (if score was $<10$ points). Knowledge score was also computed for a 10-item question on Lassa fever management and reporting. Each item was assigned ' +1 ' for correct knowledge and ' 0 ' for incorrect knowledge. The score was classified into good or appropriate (if respondent scored $>5$ points) and not good or not appropriate ( $\leq 5$ points). Bivariate chi-square test and multivariate logistic analyses were performed on respondent's characteristics and general knowledge on Lassa fever, as well as knowledge on management and reporting. Variables in the bivariate test with p-value of $<0.2$ were included in the multi-variate model. A p value $<0.05$ was accepted as significant.

\section{Ethical clearance}

Permission to conduct the study was sought from the Osun state branch of the Nigerian Medical Association, while verbal consent was obtained from every medical doctor approached to participate in the study. Permission to conduct the study was granted by the State Hospital Ethics and Research Committee (protocol no: SHO/ERC/13/007). The data collected was entered and kept in a passwordprotected computer.

\section{Results}

\section{Characteristics of respondents}

Out of 192 physicians, 5 declined participation while 9 did not return their questionnaire. Three questionnaires were excluded from analysis because of non-completeness. One hundred seventy-five questionnaires with completed data were analysed. The mean age of the study participants was $41.5 \pm 10.9$ years, majority $(78.9 \%)$ of them were males, $83.4 \%$ were married, while a larger proportion (92.6\%) were of Yoruba tribe. More than half (51.5\%) of the study participants had a post University graduation of more than 20 years to the time of the data collection, $47.3 \%$ ranged between 10 to 20 years and only $1.2 \%$ had graduated less than 10 years ago (Table 1 ). About $44.9 \%$ of the participants had more than five years of post residency training. The mean number of years of participant's clinical practice in primary, secondary and tertiary health care was 6.3, 8.8, and 6.5 years respectively.

About $18.9 \%$ of the respondents were consultants, only $16.6 \%$ were medical officers, and the rest are shown in Table 1. Some physicians worked in primary care such as General out-patient department (GOPD) (22.4\%), Family medicine (5.6\%), Community Health (8.8\%), Health centre (7.2\%) and private practice $(2.4 \%)$.

\section{Lassa fever knowledge}

Figure 1 shows that more than half $(62 \%)$ of the respondents had good general knowledge on Lassa fever. As shown in Table 2, majority (93.1\%) of the respondents knew that Lassa fever is a viral infection, $57.1 \%$ agreed that the incubation period ranges from $1-3$ weeks, and $85.2 \%$ agreed the infection can be characterized by fever $>38^{\circ} \mathrm{C}$. Majority $(82.9 \%)$ of the respondents reported that cases can not be confirmed without laboratory diagnosis, and $98.2 \%$ of them disagreed to 'pediatrics clients being excluded from diagnoses'. Only $34.8 \%$ of the respondents agreed that aerosol transmission 
Table 1 Respondent's characteristics

\begin{tabular}{ccc}
\hline Variable & Frequency $(\mathbf{n})$ & Percentage $(\%)$ \\
\hline Age: & 2 & 1.4 \\
20-24 years & 18 & 12.2 \\
25-29 years & 26 & 17.6 \\
30-34 years & 30 & 20.3 \\
35-39 years & 72 & 48.6 \\
$\geq$ 40 years & & \\
Gender: & 138 & 78.9 \\
Male & 37 & 21.1 \\
Female & & \\
Ethnicity: & 162 & 92.6 \\
Yoruba & 8 & 4.6 \\
Igbo & 5 & 2.9 \\
Other & &
\end{tabular}

Year of graduation:

More than 20 years

10-20 years

Less than 20 years

Years of post residency:

$$
\begin{aligned}
& \leq 5 \text { years } \\
& >5 \text { years }
\end{aligned}
$$

Primary clinical practice:

$$
\begin{aligned}
& \text { Yes } \\
& \text { No }
\end{aligned}
$$

Secondary clinical practice:

$$
\begin{aligned}
& \text { Yes } \\
& \text { No }
\end{aligned}
$$

Tertiary clinical practice:

$$
\text { Yes }
$$$$
\text { No }
$$

Designation:

Consultant

Medical officer

Other

Senior medical officer

$$
\text { Registrar }
$$

Chief medical officer

Senior registrar

House officer

Principal medical officer

Department:

A \& E
Anesthesia
Biochemistry

Table 1 Respondent's characteristics (Continued)

\begin{tabular}{ccc}
\hline Community health & 11 & 8.8 \\
ENT & 2 & 1.6 \\
Family medicine & 7 & 5.6 \\
GOPD & 28 & 22.4 \\
Health centre & 9 & 7.2 \\
Internal medicine & 3 & 2.4 \\
Anatomy & 1 & 0.8 \\
O \& G & 6 & 4.8 \\
Ophthalmology & 3 & 2.4 \\
Oral path/OMS & 3 & 2.4 \\
Orthopaedics & 1 & 0.8 \\
Pediatrics & 4 & 3.2 \\
Private practice & 3 & 2.4 \\
Psychiatry & 1 & 0.8 \\
Radiology & 1 & 0.8 \\
Surgery & 17 & 13.6 \\
Hospital board & 1 & 0.8 \\
\hline
\end{tabular}

of the infection is possible, while $43.0 \%$ reported semen of case being capable of transmitting infection.

\section{Knowledge on Lassa fever treatment}

Table 3 shows the response of the participants to knowledge of Lassa fever treatment. Ribavirin was reported by $80.6 \%$ of the respondents as the drug used for treatment of Lassa fever, other drugs listed were Corticosteroid (5.6\%), Ranitidine (5.6\%), and antiviral drug (8.2\%). Majority $(61.2 \%)$ of the respondents reported absence of bleeding to be a good prognostic sign during Lassa fever treatment.

\section{Knowledge on Lassa fever reporting}

Few (19.4\%) of the respondents agreed that a critical number of cases must be observed before reporting,

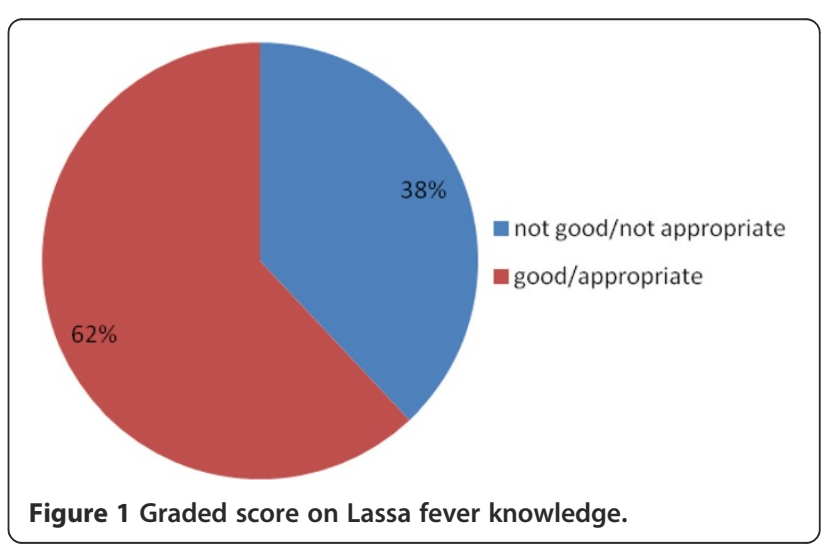


Table 2 Lassa fever knowledge

\begin{tabular}{ccc}
\hline Variable & $\begin{array}{c}\text { Frequency } \\
\text { (n) }\end{array}$ & $\begin{array}{c}\text { Percentag } \\
\text { (\%) }\end{array}$ \\
\hline Lassa fever is a viral disease: & 163 & 93.1 \\
Yes & 5 & 2.9 \\
No & & \\
Incubation period ranges for 1-3 weeks: & 100 & 57.1 \\
Yes & 64 & 36.6 \\
No & & \\
Reservoir - rat: & 169 & 96.6 \\
Yes & 3 & 1.7 \\
No & & \\
Yes & 34 & 19.4 \\
No & 131 & 74.9
\end{tabular}

Cases are characterized by fever $>38^{\circ} \mathrm{C}$ :

$\begin{array}{cc}\text { Yes } & 144 \\ \text { No } & 25\end{array}$

Retrosternal pain is a common symptom:

$\begin{array}{lll}\text { Yes } & 66 & 41.5 \\ \text { No } & 93 & 58.5\end{array}$

Bleeding from mucosal surface is a sign:

$\begin{array}{lll}\text { Yes } & 142 & 84.5 \\ \text { No } & 26 & 15.5\end{array}$

Vomiting and shock is rarely observed:

$\begin{array}{ccc}\text { Yes } & 43 & 25.3 \\ \text { No } & 127 & 74.7\end{array}$

Proteinuria is suggestive:

$\begin{array}{lcc}\text { Yes } & 44 & 27.2 \\ \text { No } & 127 & 72.8\end{array}$

Fever refractory to treat and mucosal bleeding is a sign:

$$
\begin{aligned}
& \text { Yes } \\
& \text { No }
\end{aligned}
$$

Absence of profuse mucosal bleeding exclude diagnosis:

$$
\text { Yes }
$$$$
\text { No }
$$

Pediatrics clients are excluded from diagnosis:

$$
\text { Yes }
$$$$
\text { No }
$$

Cases can be confirmed without lab

$$
\text { diagnosis: }
$$

$$
\text { Yes }
$$

\section{6} 6.6 7

\begin{tabular}{|c|c|c|}
\hline \multicolumn{3}{|c|}{ Aerosol transmission: } \\
\hline Yes & 57 & 34.8 \\
\hline No & 107 & 65.2 \\
\hline \multicolumn{3}{|c|}{$\begin{array}{l}\text { Causative organism penetrates } \\
\text { unbroken skin: }\end{array}$} \\
\hline Yes & 37 & 22.8 \\
\hline No & 125 & 77.2 \\
\hline \multicolumn{3}{|c|}{$\begin{array}{c}\text { Cases cease to be infectious after } \\
\text { acute phase: }\end{array}$} \\
\hline Yes & 18 & 11.0 \\
\hline No & 146 & 89.0 \\
\hline \multicolumn{3}{|c|}{$\begin{array}{l}\text { Semen of case is capable of transmitting } \\
\text { infection: }\end{array}$} \\
\hline Yes & 71 & 43.0 \\
\hline No & 94 & 57.0 \\
\hline \multicolumn{3}{|c|}{ Jaundice is a common manifestation: } \\
\hline Yes & 103 & 62.4 \\
\hline No & 62 & 37.6 \\
\hline \multicolumn{3}{|c|}{$\begin{array}{l}\text { Bodies of dead cases constitute } \\
\text { potential harm: }\end{array}$} \\
\hline Yes & 122 & 73.1 \\
\hline No & 45 & 26.9 \\
\hline
\end{tabular}

5

4.5 5.5

4.7
Table 2 Lassa fever knowledge (Continued)

\begin{tabular}{|c|c|c|}
\hline Variable & Frequency (n) & Percentage (\%) \\
\hline \multicolumn{3}{|c|}{ Drug used for treatment: } \\
\hline Ribavirin & 29 & 80.6 \\
\hline Corticosteroid & 2 & 5.6 \\
\hline Ranitidine & 2 & 5.6 \\
\hline Antiviral drug & 3 & 8.2 \\
\hline \multicolumn{3}{|c|}{ Patients nursed in open wards: } \\
\hline Yes & 7 & 4.5 \\
\hline No & 133 & 84.7 \\
\hline Not sure & 17 & 10.8 \\
\hline \multicolumn{3}{|c|}{$\begin{array}{l}\text { Corticosteroids important in } \\
\text { management: }\end{array}$} \\
\hline Yes & 53 & 34.2 \\
\hline No & 31 & 20.0 \\
\hline Not sure & 71 & 45.8 \\
\hline \multicolumn{3}{|c|}{$\begin{array}{c}\text { Absence of bleeding good } \\
\text { prognostic sign: }\end{array}$} \\
\hline Yes & 98 & 61.2 \\
\hline No & 16 & 10.0 \\
\hline Not sure & 46 & 28.8 \\
\hline
\end{tabular}

entage

\section{1}

.9

\section{Table 3 Treatment agent}


while $80.6 \%$ did not agree to that. Most $(82.5 \%)$ of the participants agreed that suspected cases qualify for reporting, while $73 \%$ agreed that confirmed cases can be reported. More than half (61.1\%) of the respondents reported that it is not true that cases should be reported weekly for administrative efficiency (Table 4).

\section{Respondent's characteristics and Lassa fever knowledge}

Table 5 shows the association of respondent's characteristics with knowledge of Lassa fever. A higher proportion $(77.3 \%)$ of the respondents who were older than 40 years had an appropriate knowledge on Lassa fever, compared to $21.9 \%$ of those who were younger than 40 years, although this was not significant $(\mathrm{p}=1.000)$. Surprisingly, a significantly higher proportion (35.8\%) of the respondents who did not have clinical practice in a secondary health facility had an appropriate knowledge on Lassa fever, compared to $19.8 \%$ of those who were had practiced in a secondary health facility $(\mathrm{p}=0.049)$.

\section{Predictors of knowledge on Lassa fever}

Table 6 shows the result of the multivariable model. Respondents who were not practicing at a secondary health

Table 4 Knowledge on Lassa fever reporting

\begin{tabular}{|c|c|c|}
\hline Variable & Frequency (n) & Percentage (\%) \\
\hline \multicolumn{3}{|c|}{$\begin{array}{l}\text { Critical minimum number of cases } \\
\text { must be observed before reporting: }\end{array}$} \\
\hline True & 30 & 19.4 \\
\hline Not true & 125 & 80.6 \\
\hline \multicolumn{3}{|c|}{ Suspected case: } \\
\hline True & 138 & 82.5 \\
\hline Not true & 28 & 17.5 \\
\hline \multicolumn{3}{|c|}{ Confirmed case: } \\
\hline True & 43 & 27 \\
\hline Not true & 116 & 73 \\
\hline \multicolumn{3}{|c|}{ Weekly reporting: } \\
\hline True & 58 & 38.9 \\
\hline Not true & 91 & 61.1 \\
\hline \multicolumn{3}{|l|}{ Federal: } \\
\hline True & 79 & 50 \\
\hline Not true & 79 & 50 \\
\hline \multicolumn{3}{|l|}{ State: } \\
\hline True & 83 & 52.5 \\
\hline Not true & 75 & 47.5 \\
\hline \multicolumn{3}{|l|}{ Local: } \\
\hline True & 67 & 43.8 \\
\hline Not true & 86 & 56.2 \\
\hline
\end{tabular}

Table 5 Association between respondent's characteristics and Lassa fever knowledge

\begin{tabular}{|c|c|c|c|c|}
\hline \multirow[b]{2}{*}{ Variable } & \multicolumn{2}{|c|}{ Knowledge } & \multirow[b]{2}{*}{$x^{2}$} & \multirow[b]{2}{*}{ P-value } \\
\hline & Appropriate & $\begin{array}{c}\text { Not } \\
\text { appropriate }\end{array}$ & & \\
\hline \multicolumn{5}{|l|}{ Age: } \\
\hline$<40$ years & $14(21.9)$ & $50(78.1)$ & & \\
\hline$\geq 40$ years & $51(77.3)$ & $15(22.7)$ & 0.907 & 1.000 \\
\hline \multicolumn{5}{|l|}{ Gender: } \\
\hline Male & $31(25.8)$ & $89(74.2)$ & & \\
\hline Female & $22(75.9)$ & $7(24.1)$ & 0.851 & 1.000 \\
\hline \multicolumn{5}{|l|}{ Ethnicity: } \\
\hline Yoruba & $34(24.6)$ & $104(75.4)$ & & \\
\hline Igbo & $3(37.5)$ & $5(62.5)$ & & \\
\hline Other & $1(33.3)$ & $2(66.7)$ & 0.757 & 0.685 \\
\hline \multicolumn{5}{|l|}{ Marital status: } \\
\hline Currently married & 34 (26.6) & $94(73.4)$ & & \\
\hline Currently not married & $4(19.0)$ & $17(81.0)$ & 0.414 & 0.594 \\
\hline \multicolumn{5}{|l|}{ Years of graduation: } \\
\hline More than 20 years & $20(26.7)$ & $55(73.3)$ & & \\
\hline 10-20 years & $16(23.2)$ & $53(76.8)$ & 0.865 & 0.471 \\
\hline \multicolumn{5}{|l|}{ Less than 10 years } \\
\hline \multicolumn{5}{|l|}{ Years of residency: } \\
\hline$\leq 5$ years & $6(27.3)$ & $16(72.7)$ & & \\
\hline$>5$ years & $5(25.0)$ & $15(75.0)$ & 0.867 & 1.000 \\
\hline \multicolumn{5}{|l|}{ Primary health care } \\
\hline practice: Yes & $13(20)$ & $52(80)$ & & \\
\hline No & $25(29.8)$ & $59(70.2)$ & 0.175 & 0.190 \\
\hline \multicolumn{5}{|l|}{ Secondary health care } \\
\hline practice: Yes & 19 (19.8) & $77(80.2)$ & & \\
\hline No & 19 (35.8) & $34(64.2)$ & 0.031 & 0.049 \\
\hline \multicolumn{5}{|l|}{ Tertiary health care } \\
\hline practice: Yes & $23(26.7)$ & $63(73.3)$ & & \\
\hline No & $15(23.8)$ & $48(76.2)$ & 0.685 & 0.708 \\
\hline
\end{tabular}

care level were more likely to have an appropriate knowledge on Lassa fever (OR $=0.41,95 \% \mathrm{CI}=0.192-0.889)$.

Association between respondent's characteristics and knowledge on management and reporting of Lassa fever A higher proportion (42.6\%) of respondents who were males were more likely to have a good knowledge on

Table 6 Logistic regression for respondent's characteristics and Lassa fever knowledge

\begin{tabular}{cccc}
\hline Variable & OR & 95\% Cl & P-value \\
\hline Primary health care practice & 0.54 & $0.245-1.180$ & 0.122 \\
Secondary health care practice & 0.41 & $0.192-0.889$ & 0.024 \\
\hline
\end{tabular}


Lassa fever management and reporting, compared to females (34.3\%), $\mathrm{p}=0.244$. Respondents who had more than 20 years of post graduation from medical school had a higher (49.4\%) level of knowledge on Lassa fever management and reporting, compared to those who had less than 20 years of post graduation (33.3\%), $\mathrm{p}=0.031$ (Table 7).

\section{Predictors of knowledge on Lassa fever management and reporting}

In the multi-variate analysis, the only factor that was significantly predictive of knowledge on Lassa fever management and reporting was years of graduation. Table 8 shows that respondents who had post graduation year more than 20 years were more likely to have

Table 7 Association between respondent's characteristics and knowledge on management and reporting of Lassa fever

\begin{tabular}{|c|c|c|c|c|}
\hline \multicolumn{5}{|c|}{ Knowledge } \\
\hline Variable & Good & Fair & $x^{2}$ & p-value \\
\hline \multicolumn{5}{|l|}{ Age: } \\
\hline$<40$ years & $29(40.3)$ & $43(59.7)$ & & \\
\hline$\geq 40$ years & $30(44.1)$ & $38(55.9)$ & 0.211 & 0.386 \\
\hline \multicolumn{5}{|l|}{ Gender: } \\
\hline Male & $55(42.6)$ & $89(74.2)$ & & \\
\hline Female & $12(34.3)$ & $7(24.1)$ & 0.794 & 0.244 \\
\hline \multicolumn{5}{|l|}{ Ethnicity: } \\
\hline Yoruba & $59(39.1)$ & $92(60.9)$ & & \\
\hline $\operatorname{lgbo}$ & $4(50.0)$ & $4(50.0)$ & & \\
\hline Other & $4(80.0)$ & $1(20.0)$ & 3.646 & 0.162 \\
\hline \multicolumn{5}{|l|}{ Marital status: } \\
\hline Currently married & $59(42.1)$ & $81(57.9)$ & & \\
\hline Currently not married & $4(33.3)$ & $16(66.7)$ & 0.658 & 0.281 \\
\hline \multicolumn{5}{|l|}{ Years of graduation: } \\
\hline$>20$ years & $40(49.4)$ & $41(50.6)$ & & \\
\hline$\leq 20$ years & $25(33.3)$ & $50(66.7)$ & 4.127 & 0.031 \\
\hline \multicolumn{5}{|l|}{ Years of residency: } \\
\hline$\leq 5$ years & $10(41.7)$ & $14(58.3)$ & & \\
\hline$>5$ years & $7(31.8)$ & $15(68.2)$ & 0.478 & 0.351 \\
\hline \multicolumn{5}{|l|}{ Primary health care } \\
\hline practice: Yes & $25(39.1)$ & $39(60.9)$ & & \\
\hline No & $10(45.5)$ & $12(54.5)$ & 0.277 & 0.389 \\
\hline \multicolumn{5}{|l|}{ Secondary health care } \\
\hline practice: Yes & $45(42.5)$ & $61(57.5)$ & & \\
\hline No & $2(33.3)$ & $4(66.7)$ & 0.194 & 0.503 \\
\hline \multicolumn{5}{|l|}{ Tertiary health care } \\
\hline practice: Yes & $38(40.4)$ & $56(59.6)$ & & \\
\hline No & $1(50.0)$ & $1(50.0)$ & 0.740 & 0.650 \\
\hline
\end{tabular}

Table 8 Logistic regression for respondent's characteristics and knowledge on Lassa fever management and reporting

\begin{tabular}{cccc}
\hline Variable & OR & $\mathbf{9 5 \%} \mathbf{C l}$ & p-value \\
\hline Gender: Male & 0.86 & $0.38-1.96$ & 0.72 \\
Female & 1 & & \\
Ethnicity: & & & \\
Yoruba & 1 & & 0.56 \\
Igbo & 0.65 & $0.15-2.77$ & 0.08 \\
Other & 0.13 & $0.01-1.28$ & 0.032 \\
Year of graduation: & & & \\
$>$ 20 years & 0.48 & $0.24-0.94$ & \\
$\leq$ 20 years & 1 & & \\
\hline
\end{tabular}

a good knowledge compared to those who had 20 years or lesser post graduation experience $(\mathrm{OR}=0.48,95 \%$ $\mathrm{CI}=0.24-0.94)$.

\section{Discussion}

This study assessed the knowledge, diagnosis, and reporting of Lassa fever by physicians in Nigeria. Specifically, nearly all respondents had practiced medicine for $>10$ years. Despite this, none of the respondents had managed or reported a suspected case of Lassa fever. This was probably because Lassa fever is not one of the differential diagnoses usually considered when patients with febrile illnesses present for evaluation. Several studies on Lassa virus detection have reported that misdiagnoses are common among physicians due to the non-consideration of Lassa fever as a cause of febrile illness and the non-specific clinical signs and symptoms of a large proportion of Lassa infections, combined with the lack of familiarity of physicians with Lassa fever, suggesting that the infection can easily be misdiagnosed [18-22].

However, most physicians interviewed had appropriate knowledge of Lassa fever. Thus, a disconnect between knowledge and practice as probable cases could have presented to these physicians that had been misdiagnosed leading to progression of the disease as seen in areas with low reporting of Lassa fever [21-23]. It is therefore essential that physicians, especially those practicing in primary care, should be targeted in training on emerging diseases to increase their index of suspicion and protect themselves from exposure to this deadly virus. This training will help every physician, whether they have 'good' or 'poor' knowledge regarding the diagnosis, management, and reporting of Lassa fever. The training should emphasize the concept of universal precautions, which must be observed by every health care worker while interacting with every patient [24-27].

Although all respondents believe the State Ministry of Health and their hospital pharmacy should stock Ribavirin, 
which is used for post-exposure prophylaxis by all contacts of suspected cases [24,27], none of the physicians could state categorically that Ribavirin is available at all times in the hospitals with which they are affiliated. Also, no physician had the occasion to prescribe the drug previously. This showed the low-risk perception among these physicians of Lassa fever, implying that more efforts should be made by an appropriate authority to make Ribavirin available in all hospitals and equally inform the health care workers for easy access by contacts of suspected cases.

The limitation of this study was that only physicians present at the NMA continuous medical education conference were included. Although, we expected that the programme would require the participation of all doctors, this was not so based on the number who attended. We recognized that selection bias may have occurred as those who attended may be different in some characteristics (which may affect the outcome of the study) from those who did not attend, limiting the generalization of our study findings. However, the type of physicians who see the Lassa fever cases initially are generally primary care physicians, who work in private and public owned health care facilities. These practitioners formed about half $(46.4 \%)$ of the study participants. Also, the study was cross-sectional and used a self-administered questionnaire. However, to the best of our knowledge, this is the first study to be conducted on the diagnosis and reporting of Lassa fever in the study area. This therefore serves as a baseline study to implement interventions to control possible epidemics of Lassa fever in the study area.

\section{Conclusion}

In conclusion, despite having an appropriate knowledge about Lassa fever, no suspected case has ever been diagnosed or reported by the physician participants. It is necessary to improve physician knowledge and practice on Lassa fever through continuous medical education. It is equally essential to ensure implementation of Lassa fever diagnostics and surveillance.

\section{Competing interests}

The authors declare that they had no competing interests.

\section{Authors' contributions}

SAO and AAF made substantial contributions to conception and design of the study while all the authors were involved in data collection, analysis and interpretation. All authors were involved in writing the manuscript and approved the final copy.

\section{Acknowledgement}

The authors wished to thank the executive members of the Osun state Nigerian Medical Association and physicians that participated in this study.

\section{Author details}

'Department of Community Health, Faculty of Clinical Sciences, College of Health Sciences, Obafemi Awolowo University, lle-lfe, Osun state, Nigeria. ${ }^{2}$ Department of Epidemiology and Medical Statistics, University of Ibadan,
Ibadan, Nigeria. ${ }^{3}$ Department of Maxillofacial Surgery, University of Ibadan, Ibadan, Nigeria. ${ }^{4}$ Department of Preventive Medicine, State Specialist Hospital, Asubiaro, OsogboOsun-State, Nigeria.

Received: 2 January 2014 Accepted: 17 June 2014

Published: 20 June 2014

\section{References}

1. Macher AM, Wolfe MS: Historical Lassa fever reports and 30-year clinical update. Emerg Infect Dis 2006, 12(5):835-837. http://www.ncbi.nlm.nih.gov/ pmc/articles/PMC3374442/. doi: 10.3201/eid1205.050052.

2. Ibekwe T: Lassa fever: the challenge of curtaining a deadly disease. Pan Afr Med J 2012, 11:55. http://www.panafrican-med-journal.com/content/ article/11/55/full/.

3. Richmond JK, Baglole DJ: assa fever: epidemiology, clinical features, and social consequences. BMJ 2003, 327(7426):1271-1275. doi: http://dx.doi. org/10.1136/bmj.327.7426.1271

4. Lecompte E, Fichet-Calvet E, Daffis S, Koulemou K, Sylla O, Kourouma F, Dore A, Soropogui B, Aniskin V, Allali B, Kan KS, Lalis A, Koivogui L, Gunther S, Denys C, Meulen J: Mastomys natalensis and Lassa Fever, West Africa. Emerg Infect Dis 2006, 12(12):1971-1974. doi: 10.3201/eid1212.060812 DOI:10.3201\%2Feid1212.060812\#pmc_ext.

5. Kitching A, Addiman S, Cathcart S, Bischop L, Krahé D, Nicholas M, Coakley J, Lloyd G, Brooks T, Morgan D, Turbitt D: A fatal case of Lassa fever in London, January 2009. Euro Surveill 2009, 14(6). http://www. eurosurveillance.orgNiewArticle aspx? Articleld=19117.

6. Yun NE, Walker DH: Pathogenesis of Lassa fever. Viruses 2012, 2031-2048:4. doi: 10.3390/v4102031.

7. Salazar-Bravo J, Ruedas LA, Yates TL: Mammalian reservoirs of arenaviruses. Curr Top Microbiol Immunol 2002, 262:25-63. http://www.ncbi. nlm.nih.gov/pubmed/11987807.

8. Lassa Fever Fact Sheet. Centers for Disease Control and Prevention. http:// www.cdc.gov/ncidod/dvrd/spb/mnpages/dispages/Fact_Sheets/ Lassa_Fever_Fact_Sheet.pdf.

9. Safronetz D, Lopez JE, Sogoba N, Traore SF, Raffel SJ, Fischer ER, Ebihara H, Branco L, Garry RF, Schwan TG, Feldmann H: Detection of Lassa virus, Mali. Emerg Infect Dis 2010, 16(7):1123-1126. http://wwwnc.cdc.gov/eid/article/ 16/7/10-0146_article

10. Ehichioya DU, Hass M, Ölschläger S, Becker-Ziaja B, Chukwu COO, Coker J, Nasidi A, Ogugua O, Günther S, Omilabu SA: Lassa Fever, Nigeria, 2005-2008. Emerg Infect Dis 2010, 16(6):1040-1041. doi: 10.3201/eid1606.100080

11. Flatz $L$, Rieger T, Merkler D, Bergthaler A, Regen T, Schedensack M, Bestmann L, Verschoor A, Kreutzfeldt M, Brück W, Hanisch U-K, Günther S, Pinschewer DD: T cell-dependence of Lassa fever pathogenesis. PLoS Pathog 2010, 6:e1000836. doi:10.1371/journal.ppat.1000836.

12. Hensley L, Smith M, Geisbert J, Fritz E, Daddario-DiCaprio K, Larsen T, Geisbert T: Pathogenesis of Lassa fever in cynomolgus macaques. Virol J 2011, 8:205. http://www.virologyj.com/content/8/1/205. doi:10.1186/ 1743-422X-8-205

13. Fichet-Calvet E, Rogers DJ: Risk maps of Lassa fever in West Africa. PLoS Negl Trop Dis 2009, 3(3):e388. doi:10.1371/journal.pntd.0000388.

14. Bonner PC, Schmidt WP, Belmain SR, Oshin B, Baglole D, Borchert M: Poor housing quality increases risk of rodent infestation and Lassa fever in refugee camps of Sierra Leone. Am J Trop Med Hyg 2007, 77(1):169-175

15. Abdulraheem IS: Public Health importance of Lassa fever epidemiology, clinical features and current management review of literature. Afr J Clin Exp Microbiol 2002, 3(1):33-37.

16. Hadi CM, Goba A, Khan SH, Bangura J, Sankoh M, Koroma S, Juana B, Bah A, Coulibaly M, Bausch DG: Ribavirin for Lassa fever postexposure prophylaxis. Emerg Infect Dis 2010, 16(12):2009-2010. doi: 10.3201/ eid1612.100994

17. World Health Organisation: Lassa fever in Nigeria. In Global Alert and Response. http://www.who.int/csr/don/2012 04_04/en/.

18. Haas WH, Breuer T, Pfaff $G$, Schmitz H, Köhler $P$, Asper M, Emmerich $P$, Drosten C, Gölnitz U, Fleischer K, Günther S: Imported Lassa fever in Germany: surveillance and management of contact persons. Clin Infect Dis 2003, 36(10):1254-1258.

19. Grove JN, Branco LM, Boisen ML, Muncy IJ, Henderson LA, Schieffellin JS, Robinson JE, Bangura JJ, Fonnie M, Schoepp RJ, Hensley LE, Seisay A, Fair JN, Garry RF: Capacity building permitting comprehensive monitoring of 
a severe case of Lassa hemorrhagic fever in Sierra Leone with a positive outcome: Case Report. Virol J 2011, 8:314. doi:10.1186/1743-422X-8-3.

20. Amorosa V, MacNeil A, McConnell R, Patel A, Dillon KE, Hamilton K, Erickson BR, Campbell S, Knust B, Cannon D, Miller D, Manning C, Rollin PE, Nichol ST: Imported Lassa Fever, Pennsylvania, USA, 2010. Emerg Infect Dis 2010, 16(10):1598-1600. http://wwwnc.cdc.gov/eid/article/16/10/10-0774_article. doi: 10.3201/eid1610.100774.

21. Ignatyev G, Steinkasserer A, Streltsova M, Atrasheuskaya A, Agafonov A, Lubitz W: Experimental study on the possibility of treatment of some hemorrhagic fevers. J Biotechnol 2000, 83(1-2):67-76.

22. Colebunders R, Van Esbroeck M, Moreau M, Borchert M: Imported viral haemorrhagic fever with a potential for person-to-person transmission: review and recommendations for initial management of a suspected case in Belgium. Acta Clin Belg 2002, 57(5):233-240.

23. Hugonnet S, Sax H, Pittet D: Management of viral haemorrhagic fevers in Switzerland. Euro Surveill 2002, 7(3): http://www.cdc.gov/vhf/lassa/.

24. CDC: Lassa fever. In CDC Bulletin. 2004. http://www.cdc.gov/vhf/lassa/. Accessed 10 September 2011.

25. Inegbenebor U, Okosun J, Inegbenebor J: Prevention of Lassa Fever in Nigeria. Trans R Soc Trop Med Hyg 2010, 104(1):51-54. doi:10.1016/j. trstmh.2009.07.008

26. Ogbu O, Ajuluchukwu E, Uneke CJ: Lassa fever in West African sub-region: an overview. J Vector Borne Dis 2007, 44:1-11.

27. McCormick JB, King IJ, Webb PA, Scribner CL, Craven RB, Johnson KM, Elliott LH, Belmont-Williams R: Lassa Fever Effective therapy with ribavirin. New Eng J Med 1986, 314:20-26.

doi:10.1186/1471-2334-14-344

Cite this article as: Olowookere et al:: Diagnostic proficiency and reporting of Lassa fever by physicians in Osun State of Nigeria. BMC Infectious Diseases 2014 14:344.

\section{Submit your next manuscript to BioMed Central and take full advantage of:}

- Convenient online submission

- Thorough peer review

- No space constraints or color figure charges

- Immediate publication on acceptance

- Inclusion in PubMed, CAS, Scopus and Google Scholar

- Research which is freely available for redistribution 